\title{
A INCOMPATIBILIDADE ENTRE A ACEPÇÃO DE MORALIDADE E A RESPONSABILIDADE CULPOSA
}

\section{The incompatibility between morality acceptance and negligence}

\section{Marcella Querino Mangullo'}

Resumo: $\mathrm{O}$ tema não é novo. $\mathrm{A}$ aferição da culpa na responsabilidade de atos perpetrados em face da moralidade administrativa é talvez um dos temas mais discutidos e consolidados na jurisprudência brasileira, considerando sua previsão em apenas um dos artigos daqueles que preveem os atos de improbidade na Lei no $8.429 / 92$, e responsabilidade dolosa nos demais. No entanto, apesar de o tema já estar sedimentado, ainda não nos conformamos com essa possibilidade de responsabilidade culposa, uma vez que, a nosso ver, a culpa é incompatível com o conceito de moralidade, ainda que tal conceito não seja jurídico-positivo. Esta é a razão pela qual resolvemos rememorar a discussão.

\begin{abstract}
This is not a new theme. The gauging of guilt inside the responsibility of commited acts in the light of an administrative morality is perhaps one of the most discussed themes and one of the most consolidated ones inside the Brazilian jurisprudence, considering its prediction in only one of the articles of those whom predicted the act of improbity inside the Law 8.429/92, and premeditated responsibility on every other one. However, even though the theme has already been sedimented, we have not yet been resigned with the possibility of a fault-based responsibility, since, as far as we can see, guilt is incompatible with the concept of morality, even if that concept is not a positive-judicial one. This is why we have decided to look back into this discussion.
\end{abstract}

1 Advogada especialista em Direito Administrativo (COGEAE/PUC-SP). Mestranda em Direito Administrativo (PUC-SP). E-mail: mmangullo@hotmail.com 
Palavras-chave: Moralidade. Culpa. Responsabilidade. Incompatibilidade. Lei de Improbidade Administrativa.
Keywords: Morality. Guilt. Responsibility. Incompatibility. Administrative improbity law.

\section{INTRODUÇÃO}

A Constituição Federal de 1988 foi um marco histórico em nossa sociedade. Além de trazer inúmeros direitos aos cidadãos, considerando o passado recente da Ditadura Militar, tantos outros institutos foram expressamente previstos a fim de dar à nova ordem jurídica feição mais cidadã.

Dentre essas novidades, está a elevação do instituto da moralidade à condição de princípio constitucional, com o qual vieram inúmeras e acaloradas discussões, uma vez que não é possível extrair o seu conceito do ordenamento jurídico positivo.

No entanto, a ausência desse conceito normativo, isto é, empreendido como resultado da análise do direito positivo, não pode ser razão para que se possibilite a existência de incongruências nas normas infraconstitucionais que remetem à moralidade. Isso porque, as lições de interpretação do Direito nos mostram inúmeras formas de alcançar os sentidos e os conceitos trazidos pelas expressões usadas em nosso meio, ainda que não exista um conceito formalmente jurídico para tanto.

É o caso, por exemplo, de recorrer-se ao conceito vulgar das palavras, daquele entendimento geral, não introduzido no ordenamento jurídico, reconhecido por qualquer do povo, não necessariamente letrado em Direito, como ensina Carlos Maximiliano.

Ao tratar da interpretação gramatical, embora afirme que inexiste exegese unicamente literal, pois a interpretação é um processo uno e incindível, Carlos Maximiliano aponta alguns preceitos que a orientam, sendo um deles justamente a utilização de conceitos não técnicos, mas correspondentes à linguagem vulgar. Nesse sentido, explica: "[...] b) O juiz atribui aos vocábulos o sentido resultante da linguagem vulgar; porque 
se presume haver o legislador, ou escritor, usado expressões comuns; porém quando são empregados termos jurídicos, deve crer-se ter havido preferência pela linguagem técnica." 2

Nessa toada, vislumbramos a necessidade de, mais uma vez, retomar a discussão da previsão de responsabilidade por culpa em casos de ofensa à moralidade.

Como procuraremos aclarar nas próximas linhas, a moralidade parte de uma ideia "universal" de ética, probidade, honestidade e a sua violação, para nós, depende justamente da vontade do agente de agir em desconformidade com esses valores.

Portanto, não concebemos que as pessoas possam ser imorais por negligência, imperícia ou imprudência, tríade que completa a ideia de culpa.

\section{A ACEPÇÃO DE MORALIDADE}

Tratar da questão moral é caminhar pelos terrenos mais áridos da filosofia no Direito ${ }^{3}$. Não se divorcia completamente de nenhuma de suas três vertentes: a ontologia, a epistemologia e a axiologia. Em que pese o fato de o jurista, como cientista que é, laborar com os postulados prontos e acabados encontrados pelos jusfilósofos, como um timoneiro nos mares técnico, prático ou crítico, é inevitável sua fuga do sistema científico fundado em direção à filosofia, sob pena de mergulhar na insolubilidade.

As reflexões filosóficas sobre a moral ganharam força com Sócrates e seus discípulos Platão e Aristóteles, em superação à limitada mas não menos importante filosofia da natureza que vigia até os citados acadêmicos. Todos eles encerraram pensamentos de profundidade singular, especialmente Sócrates, cujas lições foram perpetuadas pela lavra de Platão ${ }^{4}$.

2 MAXIMILIANO, Carlos. Hermenêutica e aplicação do direito. Rio de Janeiro: Forense, 2003, p. 89.

3 Entendemos não haver uma filosofia "do", mas apenas "no".

4 Segundo Sócrates, ele não podia escrever seus pensamentos, pois "a palavra vivifica, e a escrita mumifica”. Ademais, não é possível saber se alguns manuscritos de Platão são realmente lições de Sócrates, ou se são lições do próprio Platão postas na boca de Sócrates. 
É inviável resumir a filosofia dos acadêmicos sem ser reducionista, sequer a atinente às questões morais, basicamente o centro do ensaio socrático. No entanto, o que se pode dizer em curto espaço, é que, guardadas as diferenças expressadas por eles, o resumo da obra é que as ações humanas devem ser pautadas pelas virtudes, cujo conhecimento deve ser alcançado por meio do racionalismo. Em consequência, o homem só age mal se ignorar o verdadeiro conteúdo das virtudes, de modo que deve conhecer a si mesmo para ser bom.

Contudo, como resultado da finura das ponderações acadêmicas, pode ser apressado classificar a moral professada unicamente como uma ética das virtudes, pois, em certa medida, também se encontra no campo da ética das regras". Em "Ética a Nicômaco", Aristóteles escancara a absorção de parte da ética das regras ao afirmar que parcela da virtude da justiça consiste no hábito de respeitar às leis ${ }^{6}$.

Deveras, os sábios helênicos já sabiam quão estúpido poderia ser querer isolar a moral em uma classificação, eis que a ética das regras e a ética das virtudes se completam, não se opõem. Não por outra razão, alguém já chegou a dizer que filosofia é Platão, e que todo o resto que a humanidade produziu depois dele são meras notas de rodapé dos seus pensamentos.

Malgrado, a introdução convém para elucidar porque se tornou clássica a equivocada dicotomia conceitual de moralidade entre os consequencialistas e os deontologistas no pensamento filosófico ocidental posterior, sem olvidar outras classes que não nos interessam no momento. Em apertada síntese, os primeiros entendem que uma ação deve ser julgada pelas suas consequências, enquanto os segundos defendem que uma ação deve ser avaliada pelas regras obedecidas, independentemente dos efeitos.

Immanuel Kant foi talvez um dos maiores expoentes da teoria deontológica. Embora tenha rompido com o rígido

5 Ética dos direitos e deveres.

6 ARISTÓTELES. Ética a Nicômaco. São Paulo: Nova Cultura, 1991, 4ª ed. 
dualismo que havia entre racionalistas e empiristas até o século dezoito, ele concordava com os primeiros que é ínsito à razão humana distinguir o justo do injusto, entendimento que ficou plasmado na lei moral universal que denominou "imperativo categórico”.

Em grosseira simplificação, significa que por não estar relacionado com possibilidades de escolha, o imperativo categórico é uma lei (imperativo) formal válida para todos os homens e em todos os tempos (categórico): "[...] aja segundo a máxima que você pode, ao mesmo tempo, desejar como uma lei universal."” São irrelevantes as consequências dos atos, uma vez que o importante é respeitar a lei moral universal, o admirável é agir considerando o ser humano como um fim em si mesmo, agir segundo como gostaríamos que os outros agissem em relação a nós mesmos.

Em contrapartida, provavelmente inspirado pelo pensamento hedonista iniciado por Epicuro, Jeremy Bentham foi um vanguardista do consequencialismo ao desenvolver a corrente ética utilitarista, baseada no princípio da utilidade. Registrou que a humanidade está sob o julgo da dor e do prazer, de forma que devemos nos comportar com vistas a maximizar o prazer e minimizar a dor.

No entanto, a filosofia de Bentham pecou por não resolver a questão da submissão dos indivíduos ao bem da maioria, decaindo em um dilema ético acerca da ditadura majoritária, como se a minoria com ela não dividisse um mundo comum.

A problemática não passou despercebida aos olhos de Hannah Arendt, ao afirmar que "o respeito à dignidade humana implica o reconhecimento de todos os homens ou de todas as nações como entidades, como construtores de mundos ou coautores de um mundo comum". 8

7 KANT, Immanuel, apud STOKES, Philip. Os 100 pensadores essenciais da filosofia: dos pré-socráticos aos novos cientistas. Tradução de Denise Cabral de Oliveira. Rio de Janeiro: DIFEL, 2013, p. 191.

8 ARENDT, Hannah. Origens do totalitarismo. Tradução de Roberto Raposo. São Paulo: Companhia das Letras, 2012, p. 608. 
Bem por isso, o utilitarismo puro não pode ser acolhido pela Constituição, eis que abarca evidente potencial lesivo da dignidade da pessoa humana, fundamento intangível da República (CRFB, art. 1º, III) donde se extrai uma concepção antropocêntrica do Estado e a fundamentalidade material de todos os direitos essenciais.

Não obstante, a despeito de Hans Kelsen ter sofrido enorme influência de Kant, ele não admitiu a teoria absolutista de uma lei moral universal, além de ter consignado a ideia da separação entre Direito e moral, um dos dilemas mais intrigantes e belos da filosofia no Direito:

[...] apenas há valores morais relativos - então a afirmação de que as normas sociais devem ter um conteúdo moral, devem ser justas, para poderem ser consideradas como Direito, apenas pode significar que estas normas devem conter algo que seja comum a todos os sistemas de Moral enquanto sistemas de Justiça.

[...] Sob esses pressupostos, a afirmação de que o Direito é, por sua essência, moral, não significa que ele tenha um determinado conteúdo, mas que ele é norma e uma norma social que estabelece, com caráter de devida (como devendo-ser), uma determinada conduta humana. Então, nesse sentido relativo, todo o Direito tem caráter moral, todo Direito constitui um valor moral (relativo).

[...] Por tal forma, pois, não se aceita de modo algum a teoria de que o Direito, por essência, representa um mínimo moral [...]. ${ }^{9}$

Diante disso, parece claro que Kelsen se contrapunha à teoria do mínimo ético outrora preconizada por Georg Jellinek, que apresenta o Direito apenas como representante de um mínimo de moral declarado obrigatório à sociedade.

Todavia, os círculos secantes de Miguel Reale foram certeiros ao esclarecer que o Direito comporta não só o campo

9 KELSEN, Hans. Teoria pura do direito. Tradução de João Baptista Machado. São Paulo: Martins Fontes, 1998. p. 72-74. 
da moral, mas também do imoral e do amoral, sendo certo que a constância de um círculo concêntrico em que o Direito seria sempre representação da moral corresponde à concepção ideal, ao passo que os círculos secantes expõem uma concepção real ou pragmática. ${ }^{10}$

Sem deixar de adaptá-la à sua teoria do ordenamento jurídico, ensinando que a relação entre Direito e moral é uma conexão entre ordenamentos, Norberto Bobbio expôs visão semelhante à realiana:

[...] direito e moral, segundo esse modo de ver, em parte coincidem e em parte não, o que significa que há comportamentos obrigatórios tanto para um quanto para o outro, mas, além disso, existem comportamentos moralmente obrigatórios e juridicamente lícitos, e, inversamente, comportamentos juridicamente obrigatórios e moralmente lícitos. ${ }^{11}$

Além disso, Reale conceituou a moral como "uma modalidade de conduta, cuja direção se encontra no homem mesmo como instância que valora o agir e dá a pauta do comportamento". Mencionou que a moral é um valor introspectivo do ser, manifestação espontânea de regras recepcionadas não necessariamente por um processo racional e deliberado, e arrematou:

Os homens não se vinculam em seu agir apenas por valores de transcendência, mas também se ligam por algo que está neles mesmos ou, então, nos outros homens.

Há necessidade de reconhecer que em certas formas de comportamento sentimo-nos ligados por nós mesmos. A direção que seguimos brota do que há de mais singular e recôndito em nosso ser. Praticamos determinado ato e sentimos que é reflexo ou expressão de nossa personalidade, e que, por conseguinte, o motivo de nosso agir é o homem na sua subjetividade consciente.

10 REALE, Miguel. Lições preliminares de Direito. São Paulo: Saraiva, 27. ed., 2006, p. 43.

11 BOBBIO, Norberto. Teoria do ordenamento jurídico. São Paulo: Edipro, 2. ed., 2014, p. 157. 
Quando a ação se dirige para um valor, cuja instância é dada por nossa própria subjetividade, estamos perante um ato de natureza moral. ${ }^{12}$

Noutro rumo, o teórico abrangente Robert Alexy defende a tese de que o Direito não é integrado apenas pelos dois elementos do positivismo jurídico: a legalidade autoritativa e a eficácia social, mas também por uma pretensão de correção material que rompe com o positivismo e inclui uma necessidade de correição moral nos casos de injustiça extrema. Com efeito, enquanto a legalidade autoritativa e a eficácia social manifestam a dimensão real ou factual do Direito, a pretensão de correção material declara sua dimensão ideal.

O que interessa observar é que Alexy entende questões morais como sendo questões de justiça, e que uma questão de justiça "não é nada mais que correção na distribuição e na compensação". 13

Entretanto, com a exatidão dos sábios, Miguel Reale deixou um severo alerta aos novidadeiros quanto à pretensão de correção material:

Bem mais delicado é o conflito entre os princípios de Direito Natural e os do Direito Positivo, pátrio ou comparado. É o problema da "resistência às leis injustas", ou da não-obediência ao que é "legal", mas não é "justo". Na prática, a questão se resolve, ou se ameniza, através de processos interpretativos, graças aos quais a regra jurídica "injusta" vai perdendo as suas arestas agressivas, por sua correlação com as demais normas, no sentido global do ordenamento.

Ao jurista, advogado ou juiz, não é dado recusar vigência à lei sob alegação de sua injustiça, muito embora possa e deva proclamar sua ilegitimidade ética no ato mesmo de dar-lhe execução. Mesmo porque poderá tratar-se de um ponto de vista pessoal, em contraste com as valorações prevale-

12 Idem. Filosofia do Direito. São Paulo: Saraiva, 19. ed., 2002, p. 396.

13 ALEXY, Robert. Teoria discursiva do direito. Rio de Janeiro: Forense Universitária, 2014, p. 306. 
centes na comunidade a que ele pertence, e também porque permanece intocável a lição de Sócrates, recusando-se a evadir-se da prisão, subtraindo-se à iníqua pena de morte que lhe fora imposta: "é preciso que os homens bons respeitem as leis más, para que os maus não aprendam a desrespeitar as leis boas". ${ }^{14}$

Verificar apenas uma centelha dos trabalhos filosóficos sobre a moral deixa evidente que para cada um a moral tem seu significado particular dentro do contexto em que foi pensado e escrito, mas é impossível definir um conceito único e acabado sobre o que seria moralidade em qualquer tempo, entendido por qualquer pessoa, em qualquer contexto.

Poderíamos apenas aproximar valores do que a moral deveria englobar, partindo das lições dos filósofos que se debruçaram sobre a moralidade. Em apertada síntese, a moral vincula-se aos valores da honestidade, lhaneza e ao agir sempre de acordo com o que você espera da sociedade.

Como não poderia deixar de ser, além da histórica discussão filosófica sobre o que é a moral, devemos abordar os mais eminentes doutrinadores administrativistas que trataram do princípio da moralidade.

Hely Lopes Meirelles, inspirado pelas lições de Hauriou, afirmou que o administrador não pode nunca desprezar o elemento ético de sua conduta. ${ }^{15}$ Vincula, pois, a moralidade à ética da instituição pública em que o agente atua, entendimento corrente à época de suas considerações.

Celso Antônio Bandeira de Mello, ao tratar do princípio da moralidade, insere em seu conteúdo os valores da boa-fé e da lealdade, também elevados ao status de princípios, segundo os quais a Administração deve atuar em respeito à moralidade, com sinceridade e thaneza. ${ }^{16}$

14 REALE, Miguel. Lições preliminares de Direito. p. 318, grifo nosso.

15 MEIRELLES, Hely Lopes. Direito administrativo brasileiro. São Paulo: Revista dos Tribunais, 1990, p. 79.

16 BANDEIRA DE MELLO, Celso Antônio. Curso de direito administrativo. São Paulo: Malheiros, 31. ed., 2014, p. 122. 
Por sua vez, Maria Sylvia Zanella de Pietro atrela a ofensa à moralidade a violação dos bons costumes, das regras da boa administração, dos princípios de justiça e de equidade, bem como à ideia comum de honestidade. ${ }^{17}$

Em monografia para seu doutoramento sobre o princípio da moralidade administrativa, Márcio Cammarosano ensina que o significado da moralidade deve sempre estar vinculado aos valores já integrados ao ordenamento jurídico, e exemplifica-os: lealdade, boa-fé, veracidade, entre outros. ${ }^{18}$

Veja-se que, independentemente da corrente filosófica a que nos filiamos, ou ao conceito doutrinário que aceitamos, de valores integrados ou não ao ordenamento jurídico, seja moral comum ou moral juridicizada, seja ética da instituição, sejam valores mais abrangentes, fato é que a moralidade é algo fluído, sendo impossível, ao menos a princípio, defini-la categoricamente.

Seja o filósofo que for, seja o conceito doutrinário que for, o que se depreende da exposição acima é que a moralidade pode variar de canto a canto, sendo necessário ter em mente todas as variações culturais e históricas para se conseguir determinar um conceito único, aplicável a todos indistintamente, ou, ao menos, um núcleo essencial da moralidade.

A ideia de buscar um conceito único da moralidade, aplicável a todos indistintamente, é uma das mais antigas celeumas dos filósofos e, mais tarde, dos juristas ao redor do mundo.

Não é a toa que inúmeros tentaram aproximar-se do conceito, mas apenas conseguiram delinear limites, pois a fluidez do conceito implica em diversas distinções, a considerar a cultura em que a pessoa está imersa e ao contexto histórico em que vive. Por exemplo: encarar a escravidão como imoral hoje, tratando de elaborar diversas normas para coibir tal atitude, é completamente plausível, mas, se voltarmos no tempo, à época

17 DI PIETRO, Maria Sylvia. Direito Administrativo. São Paulo: Atlas, 27. ed., 2014, p. 79.

18 CAMMAROSANO, Márcio. O princípio constitucional da moralidade e o exercício da função administrativa. Belo Horizonte: Fórum, 2006, p. 114. 
anterior à Lei Áurea, conceber a escravidão como uma imoralidade era um absurdo para a maioria.

Assim, apesar de não pretendermos extinguir a celeuma desse conceito, definindo-o de forma peremptória, considerando que tal questão acompanhou a história da filosofia e do Direito por tempos, precisamos ao menos considerar valores ou conceitos próximos que nos permitirão prosseguir na discussão do tema a que nos propomos.

Da mesma forma que muitos dos autores aqui citados e tantos outros que trataram da moralidade, parece-nos possível afirmar que a moralidade se vincula diretamente ao valor da honestidade.

Além da honestidade, podemos inserir nesse conceito, ainda, valores como o da boa-fé, da lealdade, da probidade, todos próximos de uma mesma ideia: agir em relação à sociedade como gostaria que os demais agissem em relação a você, visando sempre a boa convivência, viabilizando-a e protegendo o bem maior: a vida sadia. A propósito, há mais de dois mil anos, Ulpiano parece ter aclarado com absoluta precisão o que se entende por moralidade, conquanto a profunda sabedoria do seu adágio vá muito além: "honeste vivere, neminem laedere, suum cuique tribuere." ("viver honestamente, não lesar a ninguém e dar a cada um o que é seu.").

É por essa razão que, embora não conceituemos a moralidade, apenas a vinculamos aos valores supracitados, que podem, em nossa concepção, ser resumidos pela honestidade e pela ética. Veja-se que a moralidade não é o mesmo que honestidade ou ética, mas a ela se aproxima, e isso é suficiente para demonstrar a incompatibilidade entre a moralidade e a culpa.

\section{O CONCEITO LEGAL DE CULPA}

O conceito de culpa, diferentemente do que ocorre com a moralidade, é mais facilmente identificável. Isso porque, a lei prevê um conceito, deixando evidente quais são seus limites, seus traços, sem margem para interpretações divergentes. 
Fomos buscar na legislação e na doutrina penais tudo o que se entende sobre a culpa, tendo em vista que pensamos ser o ramo sancionador mais próximo das penas por improbidade administrativa, certamente porque a Constituição da República veda a responsabilidade objetiva na esfera penal ao prever o princípio da culpabilidade no art. $5^{\circ}$, LVII ${ }^{19}$.

O Código Penal prevê no art. 18 que se diz culposo o crime quando o agente deu causa ao resultado por imprudência, negligência ou imperícia. $O$ conceito de culpa, pois, se define pelas suas características. Apenas tomando conhecimento do que seria negligência, imprudência ou imperícia é que encontramos o real significado da culpa.

Assim, valendo-nos dos ensinamentos dos doutrinadores de Direito Penal, encontramos alguns traços do que seriam as formas de manifestação da culpa, como prevê o conceito legal.

De acordo com Damásio E. de Jesus, a imprudência pode ser encontrada sempre que o agente agir na prática de um fato perigoso. No que tange à negligência, o agente atua na ausência de precaução ou com indiferença em relação ao ato realizado. Por fim, a imperícia é a falta de aptidão para exercer determinada profissão ou arte. ${ }^{20}$

O mesmo autor ainda anota as principais diferenças entre imprudência e negligência, deixando claro que, nesta última, o agente deixa de usar a prudência exigida para aquele ato, ao passo que na imprudência a conduta é realizada com a cautela que se indica que não seja utilizada. ${ }^{21}$

Nessa mesma senda, Guilherme de Souza Nucci ${ }^{22}$ anota que a culpa é um comportamento desatencioso, cujas espécies são negligência, imprudência e imperícia. Em primeiro lugar, conceitua a imprudência como um comportamento sem cautela,

19 "LVII - ninguém será considerado culpado até o trânsito em julgado de sentença penal condenatória".

20 JESUS, Damásio E. de. Direito Penal, Volume 1: Parte Geral. São Paulo: Saraiva, $2008,29^{a}$ ed., p. 300.

21 Idem.

22 NUCCI, Guilherme de Souza. Manual de Direito Penal: parte geral : parte especial. São Paulo: Revista dos Tribunais, $7^{\text {a }}$ ed., 2011, p. 239 a 244. 
realizado com precipitação ou com insensatez. Por negligência entende-se a forma passiva de culpa, segundo este autor, na qual se assume uma atitude com descuido e desatenção, justamente quando se tem o dever de cuidado. No caso da imperícia, o conceito remonta à mesma ideia do autor anterior, ou seja, a imprudência no campo técnico; incapacidade ou inaptidão para o exercício de determinado mister.

Retrataremos, por último, o pensamento do doutrinador Luís Regis Prado, que faz interessantes observações sobre a culpa no contexto da Lei Penal.

Para o autor em questão, a imprudência pode ser traduzida como um "agir sem cautela", um afoitamento; já a negligência relaciona-se à inatividade do agente, que, podendo agir para evitar a conduta, não o faz por displicência ou desatenção; enquanto a imperícia é a inabilidade técnica para o exercício de profissão ou arte. ${ }^{23}$

Ao tratar do "tipo de injusto de ação culposo", o autor deixa evidente que não estamos a tratar do fim almejado pelo agente, mas, em verdade, na própria conduta dele, considerada displicente. Ou seja, quando se trata da culpa, o que se busca punir é a ausência do dever de cuidado, nunca a vontade do agente de atingir um fim ilícito. Aliás, é justamente a displicência que atribui à conduta a característica da ilicitude, e não o fim objetivado.

Vejamos o que ensina o doutrinador:

No delito doloso, é punida a ação ou a omissão dirigida a um fim ilícito; ao passo que no culposo, pune-se o comportamento mal dirigido a um fim irrelevante (ou ilícito). Compara-se, aqui, "a direção finalista da ação realizada com a direção finalista exigida pelo Direito. O fim perseguido pelo autor é geralmente irrelevante, mas não os meios escolhidos ou a forma de sua utilização".

23 PRADO, Luis Régis. Curso de Direito Penal Brasileiro, Volume 1 - Parte Geral. São Paulo: Revista dos Tribunais, 2010, 10ª ed., p. 347. 
Na realidade, há uma contradição essencial entre o querido e o realizado pelo autor: a direção finalista da ação não corresponde à diligência devida. Todavia, a finalidade em si serve apenas no injusto culposo para definir a ação praticada e desse modo identificar a norma objetiva de cuidado, não sendo correto buscar-lhe "um conteúdo de finalidade tipicamente relevante".

O que realmente importa na configuração do injusto culposo vem a ser a infração do cuidado objetivo devido, ou seja, a presença de uma conduta descuidada (ou conduta perigosa antecedente). Melhor explicando: "a ação descuidada é o primeiro elemento do tipo do delito culposo. É ela uma ação final ainda que o fim ao qual se dirija seja indiferente para o Direito. O Direito não desvalora essa ação final por sua finalidade senão por ser realizada de forma descuidada. A ação final deverá ser contrária ao mandato ou proibição, o que não implica que isso igualmente deva ocorrer com o conteúdo da finalidade. Nos delitos culposos não é o conteúdo da finalidade que é contrário ao Direito, mas sim o caráter descuidado da ação (final)".

Assim sendo, a conduta típica culposa é valorada negativamente por sua contradição a uma norma objetiva de cuidado.

É certo, portanto, que diferença entre delito doloso e culposo já se encontra presente na própria estrutura do tipo injusto. No delito culposo, a censura penal reside exatamente na infração ao dever objetivo de cuidado. Vale dizer: decorre da inobservância do cuidado objetivo devido ou exigível que produz um resultado material externo (ou um perigo concreto) para o bem jurídico não querido pelo autor. ${ }^{24}$

De acordo com as digressões acima, podemos inferir que na culpa não se considera o elemento volitivo, como ocorre com o dolo.

24 Idem, p. 345. 
Ponderando, ademais, as últimas considerações transcritas de Luís Regis Prado, fica evidente que a culpa não sofre qualquer ingerência da finalidade almejada pelo agente. Não se deve considerar o "querer" atingir determinado fim, apenas a falta de cuidado no ato realizado.

Pelo exposto, ao avaliarmos sob a ótica da improbidade administrativa, não se desconsidera, pois, a gravidade do descuido da coisa pública. No entanto, é preciso ponderar que as normas que resguardam a moralidade administrativa acarretam sérias consequências ao imputado, sejam jurídicas ou não, como veremos adiante.

Nesse sentido, aceitar a incompatibilidade entre a moralidade e a culpa só seria possível se não houvesse outra forma de apenar o agente de forma eficiente, sem lesão à segurança jurídica.

A culpa, pois, em qualquer de suas três espécies, prescinde da vontade, o que, no contexto dos valores atribuídos ao conceito de moralidade, denota desde logo a incompatibilidade entre os institutos.

\section{A PREVISÃO DE RESPONSABILIDADE POR CULPA NA LEI DE IMPROBIDADE}

Antes de expor os julgados dos principais tribunais do país e alguns entendimentos doutrinários sobre o tema, precisamos definir o que se entende por probidade face ao conceito de moralidade, considerando que os entendimentos doutrinários e as decisões dos tribunais relacionadas dizem respeito à possibilidade de responsabilidade por culpa nos atos previstos no art. 10 da Lei de Improbidade Administrativa.

Não nos preocupamos em levantar o histórico da moralidade e sua introdução ao ordenamento jurídico no mundo e no Brasil. Preocupamo-nos em avaliar na prática, nos casos frequentes de ofensa à moralidade em que se pode considerar a conduta culposa do agente e as suas consequências drásticas. 
Verificar em que linha os tribunais estão decidindo e em quais direções apontam os doutrinadores é importante para assinalar o que, em nosso entendimento, encontra-se de acordo com as premissas que expusemos.

Por não se tratar do nosso tema, não aprofundaremos a discussão acerca das possíveis diferenças entre os conceitos de probidade e moralidade, se querem significar a mesma coisa ou se os conceitos e seus institutos jurídicos correlatos podem ensejar regimes jurídicos diferentes, considerando a forma como foram tratados pela Constituição Federal. Todavia, apenas para justificar o porquê de tratarmos da improbidade no contexto da moralidade, precisamos evidenciar qual é o nosso entendimento sobre o tema, sem pretender exauri-lo.

A nosso ver, a probidade está contida na moralidade, é espécie do gênero, tanto é que, ao definirmos o conceito de moralidade, tratamos de citar o valor "probidade". Não nos importa, agora, se juridicamente os conceitos acarretam em consequências distintas, tais como o regime jurídico e a sua aplicabilidade; importa-nos apenas deixar claro que um conceito é indissociável do outro, uma vez que têm uma relação de continente e conteúdo - gênero e espécie.

Por essa razão é que, ao tratar da responsabilidade por culpa à vista dos atos imorais, trataremos da previsão da Lei de Improbidade em seu art. 10 e, também, do entendimento jurisprudencial e doutrinário sobre o tema.

\section{O ENTENDIMENTO JURISPRUDENCIAL SOBRE A RESPONSABILIDADE POR CULPA EM ATOS PRATICADOS CONTRAAPROBIDADEADMINISTRATIVA}

Superada essa questão dos conceitos de probidade e de moralidade, a fim de corroborar nossa preocupação com a inconsistência entre a culpa e a responsabilidade por atos que afrontem a moralidade, separamos inúmeros julgados de alguns dos tribunais brasileiros, inclusive do Superior Tribunal de 
Justiça, que comprovam o entendimento uníssono da possibilidade de responsabilidade por culpa em casos de improbidade, que para nós nada mais é do que conteúdo da moralidade.

Em primeiro lugar, destacamos o seguinte julgado do Superior Tribunal de Justiça, que evidencia o entendimento da Corte e também direciona os demais tribunais do país:

ADMINISTRATIVO E PROCESSUAL CIVIL. AGRAVO REGIMENTAL NO AGRAVO EM RECURSO ESPECIAL. IMPROBIDADE ADMINISTRATIVA. PROPAGANDA INSTITUCIONAL. ALEGADA AUTOPROMOÇÃO, COM VIOLAÇÃO AOS ARTS. 9º, CAPUT, 10 , CAPUT, E 11, CAPUT, DA LEI 8.429/92. ACÓRDÃO DE ORIGEM QUE, À LUZ DAS PROVAS DOS AUTOS, CONCLUIU PELA AUSÊNCIA DO ELEMENTO SUBJETIVO DO ATO REPUTADO ÍMPROBO E PELA INOCORRÊNCIA DE LESÃO AO ERÁRIO. PRETENSÃO RECURSAL DE CONDENAÇ̃̃O PELA PRÁTICA DE ATO DE IMPROBIDADE ADMINISTRATIVA.

REVOLVIMENTO

DO CONJUNTO FÁTICO-PROBATÓRIO. VEDAÇÃO, PELA SÚMULA 7/STJ. AGRAVO REGIMENTAL IMPROVIDO.

I. Recurso Especial interposto contra acórdão que negou provimento ao apelo ministerial, mantendo sentença de improcedência de ação civil pública, por ato de improbidade administrativa, intentada em desfavor dos agravados, pela suposta prática de ato de improbidade, consistente no indevido uso da máquina administrativa, para satisfação de interesse próprio, por meio da autopromoção, em jornal municipal, pelo que teriam incorrido em atos ímprobos previstos nos arts. $9^{\circ}$, caput, 10, caput, e 11, caput, da Lei 8.429/92.

II. Nos termos da jurisprudência do Superior Tribunal de Justiça, "a improbidade é ilegalidade tipificada e qualificada pelo elemento subjetivo da conduta do agente. Por isso mesmo, a juris- 
prudência do STJ considera indispensável, para a caracterização de improbidade, que a conduta do agente seja dolosa, para a tipificação das condutas descritas nos artigos $9^{\circ}$ e 11 da Lei 8.429/92, ou pelo menos eivada de culpa grave, nas do artigo 10" (STJ, AIA 30/AM, Rel. Ministro TEORI ALBINO ZAVASCKI, CORTE ESPECIAL, DJe de 28/09/2011).

III. No caso, o acórdão recorrido, à luz da prova dos autos, foi categórico, ao decidir: (a) pela não constatação das propagandas autopromocionais; e (b) pela não demonstração do elemento volitivo da conduta ímproba e da lesão ao Erário, concluindo pela inocorrência de ato de improbidade.

IV. Relativamente à alegada violação aos arts. 9\%, caput, 10, caput, e 11, caput, da Lei 8.429/92, a discussão, em sede de Recurso Especial, acerca da configuração do ato de improbidade administrativa, implica, necessariamente, incursão no conjunto fático-probatório dos autos, o que se mostra inviável, a teor da Súmula 7/STJ.

V. Agravo Regimental improvido.

(AgRg no AREsp 270027 / RJ, AGRAVO REGIMENTAL NO AGRAVO EM RECURSO ESPECIAL 2012/0263262-9, Relator(a) Ministra ASSU. SETE MAGALHÃES, Órgão Julgador SEGUNDA TURMA, Data do Julgamento 25/11/2014, Data da Publicação/Fonte DJe 03/12/2014).

(grifo nosso).

Nesse mesmo sentido, é o entendimento do Tribunal Regional Federal da 1a Região:

ADMINISTRATIVO E PROCESSUAL CIVIL. AÇÃO DE IMPROBIDADE ADMINISTRATIVA AJUIZADA CONTRA EX-PREFEITO. LEI 8.429/92. APLICABILIDADE. IRREGULARIDADES NA EXECUÇÃO DO CONVÊNIO. AUSÊNCIA DE DANO AO ERÁRIO. INEXIS. TÊNCIA DE DOLO. APELAÇÃO NÃO PROVIDA. 
1. A presente ação de improbidade foi ajuizada com o intuito de condenar o requerido nas sanções previstas no art. 12, II e III, da Lei 8.429/92 por suposta prática de ato de improbidade em decorrência de irregularidades na execução do Convênio 218/03 firmado com o Ministério da Integração Nacional, cujo objetivo era a construção de 18 (dezoito) bueiros e reforma de 01 (uma) escola municipal, de uma ponte e de 135 (cento e trinta e cinco) casas populares.

2. É cediço que o cumprimento parcial do objeto pactuado, por si só, não é suficiente para a condenação do demandado na prática dos atos descritos na Lei 8.429/92, sendo indispensável a existência do dano ao erário e ao menos da culpa nas hipóteses do art. 10, e do dolo nas situações descritas nos arts. $9^{\circ}$ e $11^{\circ}$.

3. Verifica-se dos documentos acostados aos autos que houve um equívoco no quantitativo necessário para o cumprimento do objeto pactuado, ou seja, o valor repassado tornou-se insuficiente para a regular execução da obra, necessitando-se, assim, de uma alteração no plano de trabalho, razão pela qual o requerido teve que fazer um remanejamento da verba recebida, estabelecendo prioridades nas obras a serem executadas.

4. Não houve desvio de verba ou até superfaturamento na execução do convênio, tendo sido o dinheiro repassado pelo Ministério da Integração Nacional - MI totalmente empregado na execução do objeto estipulado no Convênio 218/03.

5. O contexto fático-probatório é insuficiente para comprovar a prática de ato de improbidade por parte do demandado, de sorte que, inexistindo prova de dolo ou culpa na conduta imputada, sobretudo em razão da inexistência do dano ao erário ou de qualquer enriquecimento ilícito, além de não ter agido com o propósito de burlar a lei ou prejudicar a Administração, não pode aquele ser 
apenado de forma objetiva, visto que o dolo ou a má-fé são impresumíveis.

6. Apelação não provida.

(Processo Numeração Única: 0001168 98.2008.4.01.3813, AC 2008.38.13.001167-1 / MG; APELAÇÃO CIVEL, Relator DESEMBARGADORA FEDERAL MONICA SIFUENTES, Órgão TERCEIRA TURMA, Publicação 18/12/2014 e-DJF1 P. 276, Data Decisão 03/12/2014).

(grifo nosso).

Do Tribunal Regional Federal da 4a Região:

IMPROBIDADE ADMINISTRATIVA. LEI N. 8.429/1992. LEGITIMIDADE PASSIVA AD CAUSAM. PROVA DOS ATOS ÍMPROBOS. VERIFICAÇÃO. DANO AO ERÁRIO. CONDUTA CULPOSA. PENA. PROPORCIONALIDADE. PROIBIÇÃO DE PROTEÇÃO DEFICITÁRIA.

1. Comprovados em juízo (i) a conduta culposa (negligência e omissão com a destinação de medicamentos entregues sob responsabilidade da servidora detentora do cargo de Coordenadora Adjunta da $17^{\text {a }}$ Coordenadoria Regional de Saúde, encarregada pelo setor, na época), e (ii) o dano ao erário, não há como afastar a subsunção da situação fática à hipótese delineada no artigo 10, caput, da Lei n. 8.429/1992.

2. A jurisprudência pátria tem repudiado a responsabilização objetiva em âmbito de improbidade administrativa. As condutas que causam dano ao erário, todavia, na esteira do entendimento do Superior Tribunal de Justiça, admitem o agir negligente, imprudente ou imperito.

3. A penalidade aplicada mostra-se adequada, necessária e proporcional, em se tratando de 
repressão à improbidade administrativa, devendo ser prestigiada.

4. Apelações improvidas.

(Classe: AC - APELAÇÃO CIVEL, Processo: 5001375-07.2012.404.7105, UF: RS, Data da Decisão: 29/10/2014, Orgão Julgador: TERCEIRA TURMA, Fonte D.E. 29/10/2014, RelatorFERNANDO QUADROS DA SILVA).

(grifo nosso).

Na mesma senda, o seguinte julgado do Tribunal de Justiça de São Paulo:

AÇÃO CIVIL PÚBLICA. Improbidade Administrativa. Programa de Incentivo ao Plantio de Café. Leis $\mathrm{n}^{\circ}$ 1.868/97 e 1.872/97, de iniciativa do prefeito municipal. Sujeição à Lei $\mathrm{n}^{\mathrm{o}}$ $8.429 / 92$. Iregularidades apontadas pelo Tribunal de Contas do Estado. Configuradas as práticas descritas no artigo 10, incisos I e VII da Lei $\mathrm{n}^{\mathrm{o}}$ 8.429/92. O caput do art. 10, da Lei de Improbidade Administrativa admite a modalidade culposa, desde que cause lesão ao erário, demonstrado o descumprimento inescusável do dever de oficio. Existência de prova inconteste nos autos. Sentença de procedência. Recursos improvidos.
(APELAÇÃO
$\mathrm{n}^{\mathrm{O}}$
00264-
93.204.8.26.0218 GUARARAPES).
(grifo nosso).

Por fim, cotejamos o entendimento do Tribunal de Justiça do Paraná: 
DECISÃO: Acordam os Desembargadores da $4^{a}$ Câmara Cível do Tribunal de Justiça do Estado do Paraná, por unanimidade de votos, em DAR PARCIAL PROVIMENTO ao recurso de apelação, nos termos do voto da relatora. EMENTA: APELAÇÃO CÍVEL. ADMINISTRATIVO. AÇÃO CIVIL PÚBLICA. IMPROBIDADE ADMINISTRATIVA.INEXIGIBILIDADE DE LICITAC̣ÃO. AQUISIC̣ÃO DE LIVROS DIDÁTICOS PARA REDE DE ENSINO PÚBLICO. PRELIMINAR DE NULIDADE DE SENTENÇA. JULGAMENTO ANTECIPADO DO FEITO. DESNECESSIDADE DE PRODUÇÃO DE PROVA ORAL E PERICIAL. AUSÊNCIA DE VIOLAC̣ÃO AOS PRINCÍPIOS DO CONTRADITÓRIO E DA AMPLA DEFESA. PRELIMINAR REJEITADA. SENTENÇA QUE ANALISA A JUSTIFICATIVA PARA INEXIGIBILIDADE DA LICITAÇÃO. POSSIBILIDADE. AUSÊNCIA DE CONCLUSÃO LÓGICA NA MOTIVAÇÃO QUANTO À SINGULARIDADE DO MATERIAL. AQUISIÇÃO DOS LIVROS DIDÁTICOS SEM A REALIZAÇÃO DE PROCESSO LICITATÓRIO. POSTERIOR RECOLHIMENTO DAS OBRAS. PREJUÍZO AO ERÁRIO EVIDENCIADO. ELEMENTO SUBJETIVO. CULPA DA SECRETÁRIA MUNICIPAL DA EDUCAÇÃO CONFIGURADA. FALTA DE DILIGÊNCIA NECESSÁRIA NA CONDUÇÃO DO PROCEDIMENTO PARA AQUISIÇÃO DOS LIVROS DIDÁTICOS. PRÁTICA PREVISTA NO ARTIGO 10, INCISO VIII DA LEI No.8.429/1992. AUSÊNCIA DE DOLO QUE AFASTA A POSSIBILIDADE DE CONDENAÇÃO PELO TIPO DESCRITO NO ARTIGO 11, CAPUT, E INCISO I DO REFERIDO DIPLOMA LEGAL. SANÇÕES APLICÁVEIS PREVISTAS NO ARTIGO 12, INCISO II, DA LEI No.8.429/1992, CONSISTENTES NO RESSARCIMENTO INTEGRAL DO DANO, SUSPENSÃO DOS DIREITOS POLÍTICOS 
E PROIBIĊÃO DE CONTRATAR COM O PODER PÚBLICO OU RECEBER BENEFÍCIOS OU INCENTIVOS FISCAIS OU CREDITÍCIOS. PERDA DA FUNÇÃO E MULTA CIVIL. DESPROPORCIONAIS E DESARAZOADAS À CULPABILIDDE DA RÉ.EMBARGOS DE DECLARAÇÃO PARA FINS DE PREQUES. TIONAMENTO. CARÁTER PROTELATÓRIO. NÃO CONFIGURADO. EXCLUSÃO DA MULTA IMPOSTA.Contratação direta por Secretária Municipal de Educação para aquisição de livros didáticos destinados à rede municipal de ensino, sob argumento de inexigibilidade de licitação. Aparente justificativa para aquisição de determinada obra literária, com apontamento, ao final da solicitação, de outra obra literária. Ausência de conclusão lógica sobre a inviabilidade da competição para aquisição dos exemplares para atender a matéria sobre cultura afro-brasileira e indígena. Comprovação da culpa para aquisição dos livros didáticos, sem regular licitação, causando prejuízo em quantia de grande monta ao erário, ante o recolhimento das obras. Nexo de causalidade entre a conduta ilícita e o dano acarretado à municipalidade. Configurado a prática do tipo previsto no art. 10, inciso VIII da Lei no. 8.429/1992, com aplicação das sanções previstas no artigo 12 , inciso II. Ausência de comprovação do elemento subjetivo do dolo, o que afasta a condenação no tipo previsto no art. 11, caput e inciso I, da referida lei. RECURSO DE APELAC̣ÃO PARCIALMENTE PROVIDO.

(1210188-7 (Acórdão), Relator: Leonel Cunha, Processo: 1210188-7, Acórdão: 41311, Fonte: DJ: 1452, Data Publicação: 11/11/2014, Órgão Julgador: 5a Câmara Cível, Data Julgamento: 21/10/2014).

Como visto, a jurisprudência está sedimentada no sentido de que a responsabilidade por culpa é possível nos casos previstos no art. 10 da Lei de Improbidade Administrativa simplesmente 
por haver previsão legal. Entretanto, não concordamos com o entendimento difundido porque o equívoco reside na própria previsão legal de culpa.

\section{O ENTENDIMENTO DOUTRINÁRIO SOBRE O TEMA}

Como vimos, o entendimento jurisprudencial está sedimentado na possibilidade de responsabilidade por culpa, pura e simplesmente porque a lei assim determinou. A doutrina também segue nesse sentido, complementando a possibilidade de culpa apenas quando se configurar culpa grave, porquanto pequenos descuidos de boa-fé não seriam capazes de ensejar a responsabilidade por ofensa à moralidade ou à probidade administrativa.

Selecionamos alguns dos trabalhos sobre o art. 10 da Lei de Improbidade, escritos pelos principais doutrinadores que se debruçaram sobre os contornos desta norma.

Marino Pazzaglini Filho, cujo trabalho tratou de comentar cada qual dos artigos da Lei de Improbidade Administrativa, esclarece que a improbidade culposa se dá quando o resultado danoso, previsto no art. 10, é involuntário, porém previsível, decorrendo de comportamento voluntário do agente público, denotando a sua má-fé, agindo com desvio ético. ${ }^{25}$

Porém, o mesmo autor adverte que não é qualquer erro ou inabilidade que seria configuradora de improbidade administrativa. Para ele, erros de boa-fé não seriam capazes de ensejar a caracterização das condutas da Lei no 8.429/92, sendo certo que somente nos casos de evidente má-fé é que caberia responsabilizar o agente nesses termos. Explica o autor: "A LIA, em suma, alcança o agente público desonesto ou imoral, não o imperito ou inábil de boa-fé".

Nota-se, pois, um esforço hercúleo em fazer valer a redação da lei, sem quaisquer alterações, já que, ao mesmo tempo que se aceita a previsão de culpa, retira do âmbito de aplicação da

25 PAZZAGLINI FILHO, Marino. Lei de Improbidade Administrativa Comentada. São Paulo: Atlas, $3^{\mathrm{a}}$ ed., 2007, p. 78/79. 
norma o agente inábil ou imperito, duas das principais espécies de culpa.

Parece-nos que, para fins da responsabilização da Lei de Improbidade Administrativa, o autor aproximou a culpa do conceito de dolo, trazendo a necessidade de expressão de vontade, de má-fé, de fins ilícitos, do agente causador do dano à moral, à ética ou à probidade.

Castro Filho, por sua vez, em seu artigo "Alguns Aspectos Relevantes da Improbidade Administrativa", publicado no livro "Temas de Improbidade Administrativa", avalia a possibilidade de improbidade culposa, desde que não se trate de mera culpa.

De acordo com o doutrinador, "a culpa mencionada na Lei de Improbidade até pode ser considerada, mas não a mera culpa”. ${ }^{26}$ Para ele, só a culpa qualificada ou o dolo eventual é que poderiam ensejar a responsabilização nos termos da Lei n ${ }^{\circ}$ $8.429 / 92$. Segundo o autor, a questão foi solucionada em razão da construção jurisprudencial que trouxe o conceito de culpa grave, isentando o agente público inábil das penas da LIA.

Para José Roberto Pimenta de Oliveira, no entanto, a probidade não poderá ser reduzida à proteção da honestidade, razão pela qual, não se justificaria a alegação da inconstitucionalidade do art. 10 e a sua previsão de improbidade culposa. Para o autor, a redução semântica ao valor da honestidade não está autorizada pela Constituição Federal, sendo que a probidade (e, conforme nosso entendimento, também a moralidade) também abrange o zelo pela res publica. ${ }^{27}$

O autor ainda aponta que o elemento subjetivo deverá ser levado em consideração para fins de punição do agente ímprobo. A gradação da penalidade, portanto, deve considerar aqueles que agiram com culpa e diferenciá-los daqueles que agiram como dolo ou culpa gravíssima.

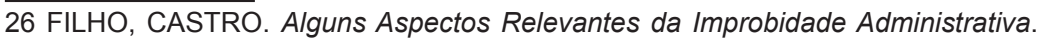
In: ALVIM, Eduardo Arruda; JORGE, Flávio Cheim e RODRIGUES, Marcelo AbeIha (org.). Temas de Improbidade Administrativa. São Paulo: Lumen Juris, 2010, p. 177.

27 OLIVEIRA, José Roberto Pimenta. Improbidade Administrativa e sua autonomia constitucional. Belo Horizonte: Fórum, 2009, p. 276. 
Não nos parece, no entanto, que a moralidade (ou probidade) não englobe também o cuidado com a res publica. É que só concebemos que sua ofensa seja responsabilizada de forma tão agressiva como prevê a Lei de Improbidade Administrativa quando o agente teve a intenção de atingir a coisa pública, ou seja, quando agiu com dolo.

Inobstante ao dever de cuidado, o que não concebemos é que a negligência seja tida como ofensa à moralidade, probidade e seus valores correlatos. Todos os valores inseridos no conceito ou ideia de moralidade implicam em "querer" agir de determinada forma, o que é incompatível com o conceito jurídico de culpa.

A ofensa à coisa pública deve ser devidamente apenada, porém não na forma como a Lei de Improbidade prevê, mas de acordo com todas as outras formas previstas no Direito para ressarcir o erário e punir quem agiu de forma negligente com a coisa do povo.

Marcelo Figueiredo, em seu livro de comentários à Lei de Improbidade Administrativa, ao tratar do art. 10 ressalta que o legislador agiu mal ao prever a possibilidade de responsabilidade culposa: "Ao que parece, o legislador infraconstitucional levou longe demais o permissivo da Lei Maior, ausentes proporcionalidade e razoabilidade no dispositivo legal." ${ }^{28}$

Note-se que este autor traz uma nova preocupação com a existência da omissão culposa, que deve ser considerada, ao menos, para fins de interpretação da Lei: a razoabilidade, princípio que orienta toda a atividade administrativa e, também, todos os operadores do Direito, seja em que função for.

Além da incompatibilidade que aqui defendemos entre culpa e moralidade, é preciso ter em mente quão drásticas são as penalidades da Lei de Improbidade em comparação aos atos do agente que incorreu em ato culposo. O objetivo dele não era enfrentar o princípio da moralidade e afastá-lo de sua atuação,

28 FIGUEIREDO, Marcelo. Probidade Administrativa - Comentários à Lei 8.429/92 e legislação complementar. São Paulo: Malheiros, 6ª Ed., 2009, p. 97. 
de modo que a perda de seus direitos de cidadania pode significar sanção muito desarrazoada nesses casos.

Deste breve levantamento é possível verificar que os autores buscaram uma forma de, sem alterar o texto constitucional, interpretar o art. 10 da Lei de Improbidade Administrativa demonstrando a possibilidade de sobreviver o elemento subjetivo da "culpa" na regra imposta.

Para alguns, a solução encontrada foi determinar que somente a culpa grave pode acarretar a responsabilidade do agente. Nessa esteira, há quem diga que a culpa grave é, em verdade, muito próxima à ideia de dolo, porque, nesse caso, poderia ser considerado até o dolo eventual, situação em que o agente assume o risco da produção do resultado.

Ou seja: a mera culpa não acarretaria a responsabilidade por ofensa à moralidade. Nesse ponto, podemos até concordar com as limitações, sem deixar de questionar: limitar à culpa grave, equiparada ao dolo, não reforça nossa proposta de que o conceito de culpa é incompatível com a moralidade e que aquela jamais alcançaria esta? É o que pensamos.

Além disso, fundamenta-se a possibilidade de culpa como elemento subjetivo que caracteriza as condutas ofensivas à moralidade, justificando-se que o conceito de moralidade engloba muito mais que honestidade. Então, o que seria a moralidade senão um conjunto de valores (juridicizados ou não) que devem ser respeitados pela sociedade, tais como a boa-fé, honestidade, probidade, lhaneza e ética? O que mais poderia a moralidade englobar? Dizer que ela abrange também o respeito à res publica não é o mesmo que dizer que o agente deve agir com honestidade e probidade em função, em respeito a toda sociedade? Parece-nos que o valor da lhaneza e da ética bem representam a moralidade e definem, sem sombra de dúvidas, a postura de qualquer um que trabalhe com a coisa pública.

Não há, pois, como justificar que a honestidade e a ética não sejam dois dos principais valores que a moralidade contém em seu conceito. 
Assim, apesar do respeitável esforço hercúleo dos doutrinadores mencionados, com vistas a fazer valer a vontade do legislador, não encontramos fundamento para solucionar a incompatibilidade com que nos deparamos: se não há vontade de fraudar a moralidade, para nós, não há como responsabilizar tão drasticamente o agente causador do dano.

Por fim, apenas porque tratamos da improbidade, é preciso ter em mente que o artigo que possibilita a responsabilidade decorrente do elemento culpa não exige a prova do enriquecimento ao erário decorrente do ato ímprobo. Em outros termos, é um tipo muito abrangente que possibilita a caracterização do menor dos descuidos como improbidade administrativa, sujeito às suas graves sanções.

\section{CONCLUSÃO}

Considerando, pois, os conceitos de culpa e de moralidade expostos, fica evidente a incompatibilidade entre um e outro. Não é possível conceber que o agente seja responsabilizado por atos que atentem à moralidade quando agiu de forma negligente, imprudente ou imperita.

Ninguém é desonesto por culpa; ninguém é antiético por negligência. Esses valores demandam a consciência e a vontade de transgredi-los pelo agente. Havendo vontade, há dolo; havendo consciência e querer, há dolo; jamais culpa, pois ela prescinde da vontade, é uma quebra do dever de cuidado objetivo.

Essas duas assertivas acima representam o resumo do que nos propusemos a expor. A moralidade é um conceito que pode ser definido por meio de outros conceitos ou de outros valores, como a probidade, a honestidade, a ética etc.

É claro que a transgressão desses valores importa vontade. É inconcebível dizer que a ética pode ser violada sem que o agente queira. Não há quem trate da corrupção, da desonestidade, sem passar pela vontade do agente em violar as normas. 
Nesse sentido, valemo-nos das lições deixadas por Norberto Bobbio em "Elogio da Serenidade", porquanto, ao tratar da relação entre ética e política, refletem bem nosso pensamento:

Basta uma breve reflexão para que se possa dar conta de que aquilo que torna moralmente ilícita toda forma de corrupção política (omitindo-se o ilícito jurídico) é a bem fundada presunção de que o homem político que se deixa corromper é aquele que antepõe o interesse individual ao interesse coletivo, o próprio bem ao bem comum, a saúde da própria pessoa e da própria família à saúde da pátria. $^{29}$

Como se vê, Bobbio foi preciso ao identificar que ofende a moralidade aquele que põe seus interesses acima dos interesses da sociedade que se propôs a auxiliar e que essa situação claramente demanda a vontade do agente em querer fazer prevalecer seu bem ao bem da sociedade.

Não bastasse isso, mesmo os julgados colacionados e alguns dos doutrinadores destacados, impõem que haja não somente a culpa do agente, mas a culpa grave para o seu enquadramento nos tipos da Lei de Improbidade Administrativa, com base no aforismo culpa lata dolo aequiparatur.

Ou seja, a mera negligência não é suficiente para responsabilizar o agente, mas a negligência grave o é. Porém, a quem cabe dizer se a culpa é grave ou não? Como aferir conceito tão vago diante de tão penosas consequências?

Mas, ainda que seja grave, será culpa - será negligência, imprudência ou imperícia - e nunca passará pela consciência do agente. Para transgredir a moralidade é preciso que haja o "querer consciente".

Há quem diga, como pontuamos acima, que a culpa grave nada mais é o do que o dolo. Isto é, haverá justamente a vontade consciente, o animus do agente, o que não se insere na ideia de

29 BOBBIO, Norberto. Elogio da Serenidade. São Paulo: UNESP, 2002, p. 83. 
culpa. Se a culpa grave é tão próximo ao dolo, isso só reforça nosso ponto. Mesmo aqueles que aceitam a possibilidade de responsabilidade nos casos de culpa grave, em verdade, aceitam a possibilidade de responsabilidade em casos de dolo. A solução dada chega à mesma conclusão: apenas o dolo deve ser considerado para esse fim.

Apesar disso, se não há vontade, mas há desrespeito às normas que regem a Administração Pública por culpa do agente, qual o problema em responsabilizá-lo por improbidade ou qualquer outra norma que proteja a moralidade? Parece-nos que a incompatibilidade entre os conceitos gera o pior dos sentimentos ao indivíduo: a insegurança.

Considerando que a segurança é justamente um dos principais valores resguardados pelo Direito, não é possível conceber a existência de tamanha incongruência conceitual no ordenamento jurídico, apta a gerar insegurança entre as pessoas.

Veja que as consequências podem ser nefastas também à Administração e, evidentemente, aos que dela dependem. A quem interessará fazer parte da Administração Pública se, em seu trabalho, não gozará de segurança? Se uma falha, a que todos nós estamos sujeitos, pois somos humanos, poderá ensejar a perda de seus direitos de cidadania, que estão entre os mais preciosos dos direitos fundamentais?

Será que a falha, ainda que grave - e veja, a gravidade decorre da jurisprudência e da doutrina, porque a lei não qualifica a culpa nesse caso -, é razão suficiente para levar ao extremo das consequências que a Lei de Improbidade prevê?

É preciso considerar que o direito foi feito para regular as relações entre homens e deve considerar, justamente, essa natureza humana: estamos, todos, sujeitos ao erro e à falha.

Será sempre possível encontrar, dentre aqueles que servem à coisa pública, alguém que possa ser considerado inábil para realizar um ou outro trabalho. Jamais conseguiremos blindar a Administração Pública ou, qualquer outra área de atuação, de 
ser composta por pessoas que, em alguma medida, serão incapazes ou inábeis para determinada atividade.

Por essa razão, ao agir é possível que determinados atos sejam prejudiciais ao erário, o que não significa que o agente teve a intenção de agravar a situação da Administração. Nesse caso, não há que se falar em ofensa à moralidade, porque todos os valores que ela resguarda dependem da vontade do agente em querer desrespeitá-la. Caberá punir o agente desidioso dentro das regras funcionais, uma vez desrespeitado seu dever funcional de cuidado ou qualquer outro existente na legislação, e, se o caso, buscar o ressarcimento ao erário.

Como visto, o próprio Direito já traz alternativas para o caso da responsabilidade culposa, já que existem outras formas de sancionar o agente que atuou eivado de culpa, em afronta aos deveres impostos pela função pública exercida. Isso não deve significar, por si só, a ofensa à moralidade.

Veja-se que não se propõe que a falha não seja punida. Existem outras tantas formas de apenar o administrador ou o administrado que incorra em graves consequências à Administração por culpa, tais como indenizações no âmbito civil e processos administrativos funcionais capazes de levar, inclusive, à demissão.

Não parece razoável, no entanto, partindo das premissas que expusemos (os conceitos), que a culpa seja razão de levar o cidadão a ter seus direitos políticos suspensos, ter que se submeter a multas altíssimas e tantas outras consequências previstas na Lei de Improbidade, ou até mesmo em qualquer outra norma que adote o ato culposo como pressuposto para a responsabilização por imoralidade.

A moralidade é um valor tão importante para a sociedade que foi elevada ao patamar de princípio constitucional. Todas as relações entre Administração e administrado devem ser regidas pela moralidade. É em razão dessa importância que as consequências de sua transgressão são tão nefastas. Na prática, basta a 
notícia entre seus pares de que está sendo processado por improbidade administrativa que passará a ser persona non grata.

Contudo, a suposta afronta carreada pelo elemento culpa a esse valor, apesar de relevantíssimo, não pode ser causa de devassa na vida do administrado ou do administrador quando agiu por ato meramente culposo.

Aliás, acreditamos que a culpa nem poderá ser considerada transgressão à moralidade, haja vista a incompatibilidade dos conceitos: se não há vontade consciente, não haverá transgressão.

Não estamos a discutir se a ofensa à moralidade deve ser combatida ou não, pelo contrário. Estamos apenas demonstrando que para ofender a moralidade é preciso que o agente aja com a intenção deliberada de desrespeitá-la, razão pela qual qualquer lei que preveja a ofensa aos preceitos da moralidade (que para nós, inclui a probidade) em virtude de comportamento meramente culposo será inconstitucional por transbordamento da discricionariedade legislativa no preenchimento do conceito cimeiro.

É por essas razões, alojadas no plano conceitual, que resistimos a aceitar a possibilidade de responsabilização por culpa em casos de afronta à moralidade e seus valores correlatos: ética, probidade e honestidade.

\section{REFERÊNCIAS}

ALEXY, Robert. Teoria discursiva do direito. Rio de Janeiro: Forense Universitária, 1a ed, 2014.

ARENDT, Hannah. Origens do totalitarismo. Tradução de Roberto Raposo. São Paulo: Companhia das Letras, 2012.

ARISTÓTELES. Ética a Nicômaco. São Paulo: Nova Cultura, 1991, 4a ed. BANDEIRA DE MELLO, Celso Antônio. Curso de direito administrativo. São Paulo: Malheiros, 2014. 
BOBBIO, Norberto. Teoria do ordenamento jurídico. São Paulo: Edipro, 2a ed., 2014.

BOBBIO, Norberto. Elogio da Serenidade. São Paulo: UNESP, 2002.

CAMMAROSANO, Márcio. O princípio constitucional da moralidade e o exercício da função administrativa. Belo Horizonte: Fórum, 2006.

FIGUEIREDO, Marcelo. Probidade Administrativa - Comentários à Lei 8.429/92 e legislação complementar. São Paulo: Malheiros, 6ª Ed., 2009, p. 97.

FILHO, CASTRO. Alguns Aspectos Relevantes da Improbidade Administrativa. In: ALVIM, Eduardo Arruda; JORGE, Flávio Cheim e RODRIGUES, Marcelo Abelha (org.). Temas de Improbidade Administrativa. São Paulo: Lumen Juris, 2010.

DI PIETRO, Maria Sylvia. Direito Administrativo. São Paulo: Atlas, 27a ed., 2014.

JESUS, Damásio E. de. Direito Penal, Volume 1: Parte Geral. São Paulo: Saraiva, 29a ed. 2008.

KELSEN, Hans. Teoria pura do direito. Tradução de João Baptista Machado. São Paulo: Martins Fontes, 1998.

MAXIMILIANO, Carlos. Hermenêutica e aplicação do direito. Rio de Janeiro: Forense, 2003.

MEIRELLES, Hely Lopes. Direito administrativo brasileiro. São Paulo: Revista dos Tribunais, 1990.

NUCCI, Guilherme de Souza. Manual de Direito Penal: parte geral: parte especial. São Paulo: Revista dos Tribunais, 7ª ed., 2011.

OLIVEIRA, José Roberto Pimenta. Improbidade Administrativa e sua autonomia constitucional. Belo Horizonte: Fórum, 2009.

PAZZAGLINI FILHO, Marino. Lei de Improbidade Administrativa Comentada. São Paulo: Atlas, $3^{a}$ ed., 2007.

PRADO, Luis Régis. Curso de Direito Penal Brasileiro, Volume 1 - Parte Geral. São Paulo: Revista dos Tribunais, 10ª Ed., 2010. 
REALE, Miguel. Lições preliminares de Direito. São Paulo: Saraiva, 27a ed., 2006.

STOKES, Philip. Os 100 pensadores essenciais da filosofia: dos pré-socráticos aos novos cientistas. Tradução de Denise Cabral de Oliveira. Rio de Janeiro: DIFEL, 2013.

Artigo recebido em 08/07/2015

Artigo aprovado em 28/08/2015 